\title{
Tegn på sindelagsskifte hos hjemmetyskerne i Haderslev 1863?
}

\author{
Af Olav Christensen.
}

Kong Frederik 7 bes $\phi$ gte i 1863 sammen med sin gemalinde, lensgrevinde Louise Danner, Sønderjylland og kom også til Haderslev, hvor magistraten og deputeretkollegiet lod afholde et bal for de høje herskaber i byens klub Harmonien, der midt under Treårskrigen var blevet oprettet af byens danske borgerskab. Her mødtes dette efter krigens afslutning med de nyudnæunte danske embedsmænd ved festlige lejligheder.

Digteren Edvard Lembeke, som var konrektor ved Haderslev lærde skole fra dens omdannelse til dansk skole i $1850 \mathrm{og}$ indtil. skolen blev tysk i 1864, har efterladt nogle erindringer, der oprindelig kun er skrevet for hans børn, men senere er udgivet. I forbindelse med en omtale af ballet for kongen og grevinde Danner giver han f $\varnothing$ lgende skildring af hjemmetyskernes stilling') :

\Også blandt hjemmetydskerne i Haderslev var der tydelige kjendetegn på et begyndende omslag i stemningen; fra de mindre fanatiske h $\phi$ rte man ofte talemåder som: $\gg$ Nu stille forholdene sig jo ganske anderledes «, og da magistraten og byrådet på byens vegne gav et bal for kongen $i$ Harmonien, mødte der flere tydskere, deriblandt min vært C. A. Petersen²) med sine damer. - Jeg er overbevist om, at hvis kongen havde levet endnu nogle år, vilde dette omslag i stemningen være bleven så stærkt og iøinefaldende, at tydskeriet i Sønderjylland vilde have fảet et dødeligt knæk.*

Lembckes samtidige og kollega Jensenius Johansen, som i 1860 var blevet kollaborator ved Haderslev lærde skole og prast ved Hertug Hans Hospitalet, giver samme billede af forholdene. Han

1) Haderslev Samfundets årsskrift 1934, s. 31 .

2) Christian Andreas Petersen (1785--1857), købmand, rådmand 1840 -50. 
fortællers), at der mod slutningen af Frederik 7's regering stadig viste sig flere tegn, »der tydede på, at hjemmetyskerne i Haderslev og særlig de mest ansete tyske familier begyndte at længes efter at få en ende på striden og opnå fastere, mere betryggende forhold «, og han fortsætter: $\gg$ En af de mest fremtrædende hjemmetyskere, tobaksfabrikant Hansent), ytrede således en dag i fortrolighed til mig, at uagtet hans sympathier, som jeg vidste, gik syd på, så gik han dog over, heller i dag end i morgen, hvis han blot turde g $\varnothing$ re regning på, at grænsen ikke atter blev flyttet mod nord «. Pastor Johansen fortæller derefter samstemmende med Lembcke om hjemmetyskernes deltagelse i Harmoniens bal for kongen og tilføjer: $\gg$ Der gik en stærk fredsluftning gennem Haderslev $i$ de dage, - der flagedes blandt andet med Dannebrog fra en stor del af hjemmetyskernes huse - *.

Men hvordan var nu de faktiske forhold, gik udviklingen $i$ national henseende virkelig i denne retning, og har de to, skolemanden og prasten, der begge var ret stærkt engagerede $i$ den nationale strid, bed $\phi \mathrm{mt}$ situationen rigtigt, eller er det kun $\phi$ nskedrømme, de her -- ganske vist på et senere tidspunkt og længe efter 1864 - gengiver som historiske kendsgerninger?

Der er ikke mange muligheder for at finde frem til oplysninger, som kan bekræfte, at de to danske embedsmiend har set rigtigt; men et enkelt lille bevis $i$ den retning, mener jeg dog at have fundet.

I disse år var det en yndet sport at afholde skydeøvelser, og en gammel fra middelalderen overleveret skik at skyde papeg $\varnothing$ jen af vandt påny udbredelse og var også nået frem til Haderslev. Her blev der i 1857 på opfordring af proprietær Jens Peter Friis, Ejsbøl, og bryggeriejer, cand. pharm. Peter Cornelius Lind oprettet en forening af skydeinteresserede. Foreningen, der eksisterer den dag i dag under navnet Haderslev Skydeselskab af 1857, havde til formål at afholde skydeøvelser i det fri og at foran-

3) J. Johansen: Oplevelser i Sønderjylland 1860-71. København 1899 , s. 27.

4) Christian Hansen (1817-1885), anden generation af det hansenske tobaksdynasti i Haderslev. 
stalte en årlig fugleskydning. Det var et udpræget dansk-nationalt selskab, hvor der under festmiddagen, som afholdtes efter de årlige fugleskydninger, altid herskede en national og patriotisk stemning *, og ved hvilke lejligheder, der blev udbragt en lang række skåler for konge og fædreland.

Det hedder således i sekretærens referat ${ }^{5}$ ) af festmiddagen efter fugleskydningen i 1861: »nationale melodier blev sungen med liv og kraft «, og »af skålerne var den første for Hans Majestæt kongen, som modtoges med rungende begejstrede hurraer «, en vending protokollen stadig gentager, eller i 1859, da sekretæren skriver, at det "navnlig var skålerne for Hans Majestæt kong Frederik $7 \mathrm{og}$ for Danmark, vort fædreland «, som modtoges $\gg$ med megen bifald af alle de tilstedeværende

Skydeselskabet talte blandt sine medlemmer et repræsentativt udsnit af den lille bys embedsstand, som efter Treårskrigen var ren dansk. Vi møder mænd som amtmand, kammerherre William Walcker Stockfleth, borgmester, etatsråd Emil Hammerich, den lærde sko!es rektor, professor S $\phi$ ren Bloch Thrige, og en lang række af lærerne, amtsforvalterne Laurids Skau og kammerråd Claus Detlev Huss, medens liberale erhverv var repræsenteret af så fremtrædende danske som apoteker Niels N. Aggersborg, fysikus Poul Anton Madvig og advokat Carl Salicath. Fra borgerskabet træffer vi så kendte mænd som rådmand Niels Sehested Gyldenfeld, konsul Amorsen, købmand P. P. Thuesen, vinhandler, klubvart Ferdinand Buhbe, og den senere formand for håndværkerforeningen, skomager Carl Christian Galatius samt brændevinsbrænder Nicolai Lundbeck, medens landbostanden var repræsenteret af folk som kammerråd Christen Hansen Juhl, Hjerndrup, sognefoged J. Scherrebeck, Vilstrup, og Peder Skau, Bukshave.

Disse navne turde være tilstrækkelige til at vise, at medlemskredsen talte en lang række af byens og egnens f $\phi$ rende danske. Selskabet var da også hurtig kommet til at nyde almindelig anseelse i den lille by, hvor borgerskabet sikkert har grebet enhver

5) Selskabets forhandlingsprotokol findes i Haderslev bylistoriske Arkiv. 
mulighed for at få lidt afveksling i det daglige liv, således at skydeselskabets fester har været et kærkomment supplement til Harmoniens.

Gennemgår vi imidlertid medlemslisten nøjere, vil vi studse over her at støde på en række navne, som vi ikke ville vente at finde $i$ et så udpræget dansk-nationalt selskab, idet de hørte hjemme i slesvig-holstenernes rakker.

Allerede fra foreningens oprettelse, eller $i$ alt fald så langt tilbage, som vi kan følge dens virke, idet der ikke findes protokollater fra selskabets f $\varnothing$ rste år, $m \phi d e r$ vi blandt de f $\emptyset$ rste 66 medlemmer f $\varnothing$ lgende navne fra slesvig-holstenske kredse:

bager Johann Georg Kuss, murermester Johann Andreas Conrad Brennecke, købmand Christian Peter Holm, jernstøber Andreas Peter Bonnichsen, købmand Hans Petersen Frey, gastgiver Christian Iversen, apoteker $H$.'Hansen, købmand Hans Christian Petersen, købmand Peter Jacob Petersen og guldsmed Johann Wilhelm Nissen.

I tiden indtil 1864 er f $\varnothing$ lgende slesvig-holstenere desuden blevet optaget som medlemmer af selskabct:

farmaceut Heinrich Hansen, jun., advokat Leopold Friedrich Finely, advokat Caspar Abraham Selig, købmand, J. P. Andersell, jun., handelskommis, senere købmand Josua Petersen og gæstgiver Jørgen Andersen Mørck.

Disse navne, der repræsenterer omkring $15 \%$ af selskabets medlemskreds, turde være tilstrækkelige til at belyse den ret store tyske islat blandt medlemmerne; men en ting er selvfølgelig at påstå, at de pågældende hørte til i slesvig-holstenernes rakker, noget andet er at bevise det. - Lad os derfor se lidt nærmere på de pågældende Haderslev-borgeres forhold.

Byens xldste endnu eksisterende forening, »Bürgerverein«, 
blev oprettet i 1838 og var, som navnet angiver, oprindelig en ren borgerforening, men udviklede sig efterhånden til at blive slesvigholstenernes højborg i Haderslev. Den må fra begyndelsen af fyrrerne anses for at være ren tysk, selv om der dengang dog endnu var enkelte danskorienterede blandt dens medlemmer. f. eks. to af dens stiftere, de stænderdeputerede k $\varnothing$ bmand Peter Hiort Lorenzen, Haderslev, der efter et intermezzo $i$ januar 1845 blev ekskluderet af foreningen, og gårdejer Nis Lorenzen, Lilholt. Hvor spegede forholdene i $\phi$ vrigt var dengang, viser Borgerforeningens medlemsfortegnelse ${ }^{b}$ ), idet så kendte danske som møller Nis Boysen, Tørning mølle, og kammerråd Christeu Juhl, Hjerndrup, endnu i 1864 stod som medlemmer, medens ikke mindre end otte af selskabet Harmoniens stiftere havde været med til at oprette eller stod som medlemmer af Borgerforeningen.

Blandt Borgerforeningens direkt $\varnothing$ rer møder vi efter 1842, da i alt fald aktiv deltagelse i foreningens virke må berettige til at karakterisere et medlem som tysk, og indtil 1870 en række af skydeselskabets medlemmer ${ }^{7}$ ) nemlig:
advokat Caspar Abraham Selig, bager Johann Georg Kuss, jernstøber Andreas Peter Bonnichsen, advokat Leopold Friedrich Finely, guldsmed Wilhelm Nissen og apoteker Hans Heinrich Hansen, jun.,

medens gæstgiver Christian Iversen, der omtales som tysksindet stænderdeputeret, var medlem af foreningen ${ }^{a}$ ).

Da Peter Hiort Lorenzen i 1845 blev ekskluderet af Borgerforeningen, blev der samtidig gjort fors $\phi g$ på at få ham udelukket fra borgerkollegiet, hvor han havde siddet som medlem fra 1835 , idet han fra slesvig-holstensk side blev beskyldt for at have været ophavsmand til og deltaget i et slagsmål i det gæstgiveri, som havde til huse i samme ejendom som Borgerforeningen. I

6) Bürgerverein zu Hadersleben. 1838 - 19. november - 1938 . Flensborg 1938, s. 31.

7) S. st. side 40 f.

8) S. st. side 32 . 
denne anledning blev der of entliggjort en adresse ${ }^{0}$, hvori der rettedes en række beskyldninger imod bl. a. Hiort Lorenzen og Laurids Skau, og hvori man fremhævede, at Slesvig-Holstens politiske rettigheder var af en anden karakter end Danmarks, og selv om man højtidelig ville forsvare sig imod beskyldninger om, at man ønskede en adskillelse fra Danmark, er adressens hele karakter dog stridende mod skydeselskabets dansk-nationale indstilling, og alligevel finder vi en række af dettes senere medlemmer blandt underskriverne, nemlig: Bonnichsen, J. W. Nissen, Joh. Georg Kuss, L. F. Finely, C. A. Selig og Christian Iversen.

Slesvig-holstenerne i Haderslev blev i lobet af 1840'erne mere og mere aktive, og den 7. januar 1845 omdannedes en eksisterende forening af sognefogeder til Den Slesvig-Holstenske Patriotiske Forening ${ }^{10}$ ), som senere fik afdelinger over hele $\$ \phi n-$ derjylland. Foreningen, hvis formål var »på lovlig måde og med alle til rådighed stående tilladte midler at fremme patriotiske anliggender «, udviklede sig hurtig til at blive et meget vigtigt organ i slesvig-holstenernes løsrivelsesbestræbelser og greb på mange måder aktivt ind $i$ nationalitetskampen og var $i$ det hele taget meget agressiv $i$ - sit virke. Som medlemmer af denne forening, der fandt sit endeligt med slesvig-holstenernes nederlag i Treårskrigen, møder vi også en række navne fra skydeselskabets medlemskreds, nemlig:

jernst $\varnothing$ ber A. Bonnichsen, 7. 7. 1845,

gæstgiver Christian Iversen, 7. 7. 1845,

købmand Petersen Frey, 4. 8. 1845,

advokat Finely, 9. 1. 1846,

bager Kuss, 21. 6. 1847, og

købmand J. P. Andersen, jun., 27. 10. 1848.

Endelig kan det oplyses, at $\mathbf{k} \phi \mathbf{b m a n d} \mathbf{P}$. J. Petersen var slesvigholstenernes kandidat ved stændervalget $\mathrm{i} 1860$, og at vi desuden efter 1864 finder f $\varnothing$ lgende af selskabets medlemmer enten som medlemmer af magistraten eller af borgerkollegiet, der begge nu kun talte tysksindede medlemmer, idet ingen dansk var indvalgt:

๑) Itzehoer Wochenblatt 1845, nr. 4, 25. januar.

10) Forhandlingsprotokol for Den Slesvig-Holstenske Patriotiske Forening (Haderslev byhistoriske Arkiv). 
k $\varnothing$ bmand Hans Petersen Frey, 1864, k $\phi$ bmand Peter Jacob Petersen, rådmand 1864-94, k $\emptyset$ bmand Christian Peter Holm, rådmand 1864-76, gæstgiver J $\emptyset$ rgen Andersen M $\phi$ rck, $1864-77$, murermester Johann Andreas Conrad Brennecke, 1864-71, jernvarefabrikant Andreas Peter Bonnichsen, 1864-69, apoteker Hans Heinrich Hansen, 1872-77, købmand Josua Petersen, 1876-91, og købmand Hans Christian Petersen, 1880-83.

Såfremt selskabets medlemsliste blev endnu nøjere gennemgået, og kilderne havde flydt lidt rigeligere, turde der sikkert være endnu flere navne at finde fra mindre fremtrædende slesvigholstenske kredse; men de anførte skulle være tilstrækkelige til at bevise, at Haderslev Skydeselskab, som ikke fors $\emptyset$ mte nogen lejlighed til at hylde kongen og fædrelandet Danmark, har talt en lang række fremtrædende slesvig-holstenere inden for sine rækker. At de ikke blot har været medlemmer af navn, beviser forhandlingsprotokollen til fulde. De møder ikke alene op og deltager i fugleskydningerne, men er også aktive på andre områder inden for selskabets virke, således var $\mathrm{k} \phi$ bmand Peter Jacob Petersen medlem af selskabets styrelse fra 1858, måske endda fra 1857, da navnene på styrelsesmedlemmerne fra det første år ikke er kendte, og til 1861, da han ikke $\varnothing$ nskede genvalg, og k $\phi$ bmand Christian Peter Holm var selskabets kasserer fra 1859 til 1861. Da selskabet i 1862 vedtager at lade opf $\varnothing$ re et skyttehus, og der i den anledning blandt medlemmerne blev tegnet aktier for 500 rdlr., finder vi blandt aktietegnerne følgende tysksindede medlemmer: advokat Finely, k $\varnothing$ bmand $P$. J. Petersen, jernst $\varnothing$ ber Bonnichsen, guldsmed W. Nissen, gæstgiver J. A. Mørck, apoteker H. Hansen og gæstgiver Chr. Iversen.

Af protokollens oplysninger vedrørende festerne efter fugleskydningerne fremgår det også, at en række af de slesvigholstenske medlemmer har deltaget $\mathrm{i}$ festmiddagen.

Det er allerede nævnt, at forholdene dengang var spegede, men et par tilfælde, hvor det tilsyneladende har varet vanskelig for en borger at få sig nationalt placeret, og hvor en fynbo efterhån- 
Peter Brodersen Hansen $1831-1878$.

Borgmester i Haderslev 1864-1867, ivrig slesvig-holstener.

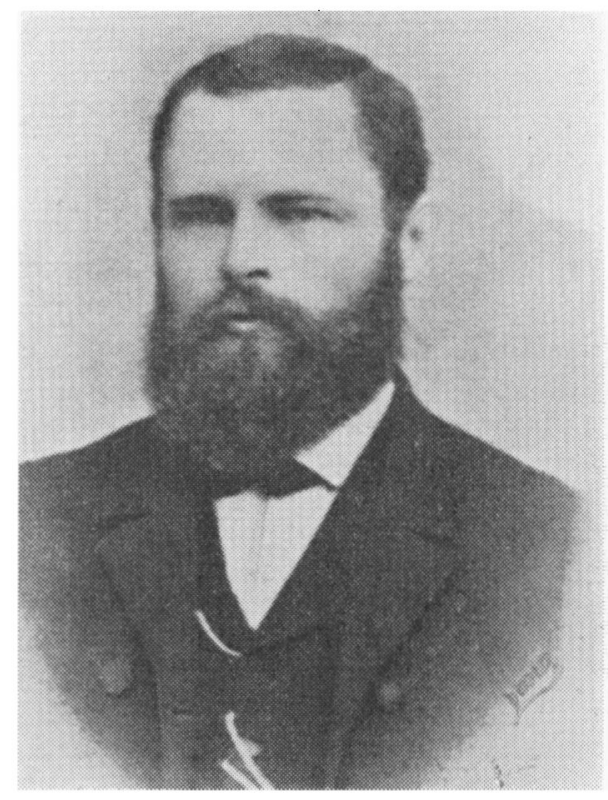

den udviklede sig til at blive ren tysk, skal dog endnu fremdrages.

Blandt skydeselskabets medlemmer møder vi vognfabrikant Jens Mordhorst, der var født i Haderslev, og som vi finder blandt underskriverne på adressen i Itzehoer Wochenblatt, men som i 1849 var med til at oprette det nationale selskab Harmonien. Han er altså efterhånden blevet helt dansk orienteret, medens det omvendte gælder for et andet medlem, tómmerhandler Hans Clausen Magaard, der var f $\varnothing \mathrm{dt}$ i Svendborg og i $1860 \mathrm{blev}$ medlem af Borgerforeningen ${ }^{11}$ ), men som - vel nok af forretningsmæssige grunde - dog ikke var blandt de tyskere, der ved regeringspræsident von Köllers bes $\varnothing \mathrm{g}$ i Haderslev i 1899 havde hejst flaget" ${ }^{12}$. Han var far til den kendte tysksindede Haderslev-læge, sanitetsråd, dr. med. Harald Magaard.

Man skulle tro, at krigen 1864 havde bragt en andring i disse

11) Bürgerverein $1838-1938$, s. 31.

12) Haderslev Samfundets årsskrift 1938, s. 23. 
forhold. Det gjorde den efterhånden også, men ikke straks, idet der i den første tid derefter stadig blev optaget slesvigbolstenere som medlemmer, hvoraf nogle enkelte navne endnu skal fremdrages her.

I 1865 blev brændevinsbrænder Jens Johannsen, der var medlem af borgerkollegiet fra $1864-1908$ og en lang tid formand for dette, optaget tillige med bager Friedrich Daniel Schley, der ligeledes var medlem af borgerkollegiet fra $1864-69$, og endelig som det mest bemærkelsesværdige blev borgmester Peter Brodersen Hansen optaget som medlem den 5 . juli 1865 . Nu synes det imidlertid også at være slut med selskabets liberale indstilling over for modstanderen, idet borgmesteren kun blev optaget med 31 ja- mod 13 nej-stemmer, medens seks andre foreslåede alle faldt igennem. De pågældende, der blev foreslået til optagelse af de tysksindede medlemmer brændevinsbrænder Jens Johannsen og gæstgiver J. A. Mørck, var:

købmand J. Jørgensen,

købmand S. Jørgensen, sognefoged I. Thomsen, Solkjær, snedker Frøleking, gæstgiver C. Schmidt, og gæstgiver M. Bramsen,

og de var alle, så vidt jeg har kunnet konstatere, slesvigholstenere. Selskabets flertal af dansksindede medlemmer har nu sikkert været klare over faren for en fortyskning og har derfor nu stemt efter politisk overbevisning, selv om de - måske for ikke at få bystyret imod sig - har ladet borgmesteren slippe igennem ganske vist kun med et knebent stemmetal, idet der krævedes totredjedele stemmeflertal for at blive optaget.

Selskabet blev nu efterhånden rent dansk, selv om de tysksindede blev stående som medlemmer $i$ alt fald $i$ de forste år. Advokat Leopold Finely optræder endnu i 1869 som fuglekonge, selv om det ganske vist skete ved lodtrækning, men fra begyndelsen af 1870 'erne er selskabet tilsyneladende også hvad medlemskredsen angår rent dansk, og det fik da også kort efter myn- 
dighedernes bevågenhed at føle $i$ form af forbud mod optog m. $v{ }^{13}$ )

De sønderjydske foreningers historie har en særlig interesse, sammenlignet med tilsvarende foreningers $i$ det gamle land. De giver ikke alene bidrag til belysning af kulturhistorien, men kan også bidrage til belysning af grænselandets politiske historie, hvilket Haderslev Skydeselskab af 1857 er et godt hevis på. Dens xldste forhandlingsprotokol synes nemlig at bekræfte, at Lembcke og Jensenius Johansen har ret $i$ den påstand, at der var et begyndende skred i slesvig-holstenernes rækker i tiden op til 1864, og at udviklingen i Haderslev måske var gået i samme retning, som den gjorde det efter $1864 \mathrm{i}$ de otte sogne, såfremt Frederik 7's pludselige d $\varnothing$ d ikke havde ændret situationen ganske og resulteret $\mathrm{i}$ den ulykkelige krig i 1864 . Det er i denne forbindelse værd at lægge mærke til en skål, købmand P. J. Petersen, der hørte til i slesvig-holstenernes rækker, i 1859 under festmiddagen udbragte for freden. Den stemmer helt overens med Jensenius Johansens udtalelse om den stærke fredsluftning, der gik over Haderslev under kongebes $\phi$ get i 1863 .

13) Olav Christensen: Haderslev Skydeselskab af 1857. Haderslev 1957, s. 25. 